\title{
Pooled Analysis of 86 Published Spinal Hydatid Cyst Cases From Turkey
}

\author{
Türkiye'den Yayınlanmış 86 Spinal Kist Hidatik Olgusunun Havuz Analizi Yöntemi ile \\ Değerlendirilmesi
}

\author{
(1) Bedia Mutay SUNTUR1, (1) Gökhan ÇAVUŞ2 \\ ${ }^{1}$ Adana City Training and Research Hospital, Clinic of Infectious Diseases and Clinical Microbiology, Adana, Turkey \\ ${ }^{2}$ Adana City Training and Research Hospital, Clinic of Neurosurgery, Adana, Turkey
}

\section{Abstract}

Introduction: Spinal hydatid cyst (SHC) is a difficult to treat parasitic infectious disease with high risk of recurrence. Similar with $\mathrm{HC}$ the visceral organs, there are no standard treatment protocols for SHC. The aim of this study was to analyze clinical and laboratory findings, treatment, and prognosis in published SHC case reports from Turkey in the last 20 years.

Materials and Methods: One national (Ulakbim, Turkish medical literature database, http://uvt.ulakbim.gov.tr/uvt/) and two international databases (www.scopus.com and www.pubmed.com) were searched for SHC case reports from Turkey published in Turkish and international journals between January 1998 and November 2018. Relevant articles were identified using the keywords "spinal kist hidatik" and "vertebral kist hidatik" in the national database and "spinal hydatid cyst and Turkey" and "vertebral hydatid cyst and Turkey" in the international databases. Of 114 articles identified in the initial search, 55 articles that met the study criteria were included in our analysis. The cases were evaluated in terms of presenting symptoms, history, physical examination findings, concurrent extraspinal involvement, diagnostic methods, spinal lesion category, treatment, and prognosis.

Results: A total of 86 cases of SHC were identified in the three databases using the specified keywords. Forty-eight (56\%) of the patients were male and the mean age was $36.4 \pm 16.8(8-73)$ years. The most common presenting symptoms were back pain (83\%), difficulty in walking (47\%), urinary and/or stool incontinence (27\%), and leg numbness (22\%). Concurrent extraspinal involvement was identified in 35\% of the patients while thoracic involvement was the most common (36\%). Extradural intraspinal was the most common lesion type. The most preferred treatment protocol was albendazole for a duration of six months. When the history and follow-up period of the patients were evaluated together, $51 \%$ of the patients had at least one recurrence.

Conclusion: SHC affects the young to middle-aged population, leading to neurological morbidities that decrease patients' quality of life. Studies are needed to determine more effective medical treatment protocols for SHC.

Keywords: Echinococcus granulosus, echinococcosis, Dew/Braithwaite \& Lees classification, mebendazole, systematic review

\section{Öz}

Giriş: Spinal kist hidatik (SKH) tedavisi zor ve nüks olasılığı yüksek paraziter bir enfeksiyon hastalığıdır. Spinal KH için viseral organların kist hidatiğine benzer şekilde standart tedavi protokolleri mevcut değildir. Bu çalışmada son 20 yılda Türkiye'den bildirilmiş SKH olgu sunumlarının klinik ve laboratuvar bulguları, uygulanan tedavi ve prognoz açısından incelenmesi amaçlanmıştır.

Gereç ve Yöntem: İki uluslararası veri tabanı (www.scopus.com ve www.pubmed.com) ve bir ulusal veri tabanı (Ulakbim Türk medikal literatür veri tabanı, http://uvt.ulakbim.gov.tr/uvt/) taranarak Ocak 1998 ve Kasım 2018 tarihleri arasında Türkiye'den yerli ve yabancı dergilerde yayınlanmış SKH olgu sunumları araştırıldı. Makaleler, ulusal veri tabanında "spinal kist hidatik", "vertebral kist hidatik"; uluslararası veri tabanlarında ise "spinal hydatid cyst and Turkey" ve "vertebral hydatid cyst and Turkey" anahtar kelimeleri ile tarandı. Tarama sonucu bulunan 114 makaleden aranan

Cite this article as: Suntur BM, Çavuş G. Pooled Analysis of 86 Published Spinal Hydatid Cyst Cases From Turkey. Mediterr J Infect Microb Antimicrob. 2019;8:7. 
kriterlere uygun olan 55 makale çalışmaya dahil edildi. Olgular, yakınma, öykü, fizik bakı bulguları, eşlik eden ekstraspinal KH, spinal lezyonun kategorisi, tanı yöntemleri, uygulanan tedavi ve prognoz açısından irdelendi.

Bulgular: Belirtilen anahtar kelimeler kullanılarak üç veri tabanında yapılan tarama sonucunda 86 SKH olgu sunumu tespit edildi. Olguların 48'i (\%56) erkek iken yaş ortalaması 36,4 16,8 (8-73 yıl) yıldı. En sık başvuru yakınmaları sırt ağrısı (\%83), yürüme güçlüğü (\%47), idrar ve/veya gaita kaçırma (\%27) ve bacaklarda uyuşukluk (\%22) şeklindeydi. Tarama yapılan olguların \%35'inde eş zamanlı ekstraspinal tutulum saptanmıştı. En sık torakal (\%36) tutulum gözlendi. Kategorik olarak ekstradural intraspinal en sık görülen SKH tipiydi. Medikal tedavide albendazol ve altı aylık tedavi süresi en çok tercih edilen tedavi protokolüydü. Öykü ve takip periyodu birlikte değerlendirildiğinde tedavi sonrasında hastaların \%51'inde en az bir kez nüks geliştiği görüldü.

Sonuç: Spinal KH, genç-orta yaş popülasyonu etkilemekte ve bu hastalarda yaşam kalitesini azaltan nörolojik morbiditelere neden olmaktadır. Daha etkin medikal tedavi protokollerini belirleyecek çalışmalara ihtiyaç vardır.

Anahtar Kelimeler: Echinococcus granulosus, ekinokokkoz, Dew/Braithwaite \& Lees sınıflaması, mebendazol, sistematik derleme

\section{Introduction}

Cystic echinococcosis, or hydatid disease, is a zoonotic parasitic infectious disease caused by Echinococcus granulosus. Mediterranean countries, including Turkey, are among the regions where cystic echinococcosis is endemic ${ }^{[1]}$. Dogs are the most important definitive host in the life cycle of E. granulosus, and humans are incidental intermediate hosts. Humans are infected by ingesting food contaminated with parasite eggs from dog feces or via direct contact with dog feces. Hydatid disease most commonly affects the liver (60-70\%) and lungs $(20-25 \%)$. Bone involvement is rare $(0.5-4 \%)^{[2]}$. Hydatid disease of bone is usually seen in the spine (54\%), followed by the pelvis $(14 \%)$, femur $(10 \%)$, and ribs $(8 \%)^{[3,4]}$.

Spinal involvement may occur as a result of spread from adjacent visceral organs or as primary involvement by hematogenous spread, without any other foci ${ }^{[5]}$. According to the Dew/ Braithwaite \& Lees classification, spinal hydatid cysts (SHC) are categorized into five types based on their anatomical location: intramedullary, intradural extramedullary, extradural intraspinal, vertebral, and paravertebral[ ${ }^{[6]}$. The signs and symptoms of SHC are usually associated with spinal cord compression and can range from simple lower back or leg pain to paraplegia. The main treatment approach is surgical removal of the cyst ideally intact and unruptured. Benzimidazole-derived anthelmintic agents are used as adjunct medical treatment ${ }^{[5,7]}$. Similar with $\mathrm{HC}$ of the liver and lung, there are no standard, well-established treatment protocols for SHC. Most studies on SHC in the literature are case reports or series. Despite advances in imaging techniques and surgical techniques, treating SHC remains a challenge, and post treatment recurrence rates are high.

The aim of this study was to analyze in SHC case reports from Turkey in national and international journals within the last 20 years in terms of clinical and laboratory findings, surgical and medical treatments, duration of medical treatment, and postoperative prognosis and recurrence.

\section{Materials and Methods}

Two international databases (www.scopus.com and www. pubmed.com) and a national database (Ulakbim Turkish medical literature database, http://uvt.ulakbim.gov.tr/uvt/) were searched to identify SHC case reports from Turkey, and published in national and international journals between January 1998 and November 2018. The literature search was conducted on November 15th, 2018, using the keywords "spinal hydatid cyst" and "vertebral hydatid cyst" in the national database and "spinal hydatid cyst and Turkey" and "vertebral hydatid cyst and Turkey" in the international databases. Of the articles identified in the initial search, those unrelated to SHC and those related to SHC but lacking sufficient data regarding clinical findings, diagnosis, and treatment were not included in our analysis ${ }^{[8]}$. Patients with SHC were evaluated in terms of age, sex, symptoms, history of spinal or extraspinal $\mathrm{HC}$, time from symptom onset to diagnosis, physical examination findings, concurrent extraspinal involvement, results of diagnostic imaging methods and Echinococcus-specific microbiological tests, spinal lesion level, Dew/Braithwaite \& Lees category, surgical and medical treatment performed, duration of treatment, and postoperative prognosis and recurrence.

\section{Statistical Analysis}

Statistical analyses were performed using SPSS version 20.0 (SPSS Inc., Chicago, IL, USA). Descriptive statistics were expressed as percentage, minimum-maximum, mean, and standard deviation. The Kolmogorov-Smirnov test was used to determine whether variables conformed to normal distribution. For comparisons between more than two groups, the KruskalWallis test was used to compare continuous variables. Fisher's Exact test was used to compare discrete variables. A p value $<0.05$ was considered statistically significant.

\section{Results}

Of the 114 articles identified by searching the three databases using the specified keywords, 59 were excluded according to 
the above outlined criteria. The remaining 55 articles contained a total of 86 SHC cases (Figure 1) ${ }^{[9-63]}$. Of these, $48(56 \%)$ were male, and the mean age was $36.4 \pm 16.8$ years ( $8-73$ years). Seventy-one patients (83\%) had complaints of mid or low back pain, $40(47 \%)$ had weakness of the legs or difficulty walking, $23(27 \%)$ had urinary and/or fecal incontinence, and $19(22 \%)$ had numbness in the legs. The mean time between symptom onset and diagnosis was 9.93 \pm 21.06 months (0-143 months). Forty-one patients (48\%) had history of SHC or extraspinal HC (31 spinal, four lung, three liver, one lung + spinal, one kidney, one rib). Of 72 patients whose physical examination findings were reported, $35(49 \%)$ had bilateral or unilateral paresis of the extremities, $20(28 \%)$ had varying dermatomal sensory deficits depending on lesion level, and $23(32 \%)$ had urinary and/or fecal incontinence. Six patients were reported to be paraplegic at time of diagnosis.

Imaging methods included magnetic resonance imaging (MRI) in 60 patients, MRI and computed tomography (CT) in 14 patients, CT in eight patients, and X-ray and myelography in four patients. Thirty-five patients underwent one or more of the following Echinococcus-specific microbiological analyses: indirect hemagglutination assay (IHA), immunofluorescence antibody assay, specific enzyme-linked immunosorbent assay (ELISA), Western blotting, and polymerase chain reaction. At least one of these tests was positive in $20(57 \%)$ of these patients (Table 2). HC diagnosis was confirmed histopathologically in 68 patients. Sixteen patients were diagnosed with $\mathrm{HC}$ based on findings of radiological imaging and two patients based on radiological imaging and microbiological test results.

Seventy-four patients were screened for extraspinal HC; extraspinal involvement was not detected in $48(65 \%)$ of these patients while $26(35 \%)$ patients had concurrent extraspinal involvement of liver $(n=5)$, lung $(n=6)$, pelvis $(n=3)$, kidney $(n=4)$, spleen $(n=1)$, heart $(n=1)$, rib $(n=1)$, lung $+\operatorname{liver}(n=1)$, lung + liver + spleen $(n=2)$, liver + pelvis $(n=2)$, and liver + cranial $(n=1)$.

Twenty-five patients had single vertebral involvement and 61 patients had involvement of multiple vertebrae. When single and multiple spinal involvement cohorts were analyzed together, it was found that 31 patients (36\%) had only thoracic, $18(21 \%)$ had only lumbar, eight (9\%) had only sacral, and five $(6 \%)$ had only cervical vertebral involvement. Twenty-four patients (28\%) had involvement of multiple regions (thoracic, lumbar, sacral, or cervical). Thoracic vertebral involvement was not statistically associated with presence of lung $\mathrm{HC}(\mathrm{p}=0.544)$. Of 65 patients whose Dew/Braithwaite \& Lees category was reported, $16(24.6 \%)$ had extradural intraspinal, $13(20 \%)$ had intradural extramedullary, $12(18.4 \%)$ had vertebral, 10 $(15.3 \%)$ had vertebral + paravertebral, six (9.2\%) had extradural intraspinal + paravertebral (dumbbell formation), four (6.1\%) had extradural intraspinal + vertebral + paravertebral, two (3\%) had paravertebral, and two (3\%) had intramedullary SHC (Table 3). There were no significant differences in age distribution between the categories $(p=0.61)$.

Analysis of the 84 patients with treatment data showed that 16 underwent cyst excision alone, 61 had cyst excision with decompression surgery, three had percutaneous cyst drainage, two patients underwent surgery for concurrent extraspinal $\mathrm{HC}$ but did not have spinal surgery, and two patients did not undergo any surgical interventions. The records of 45 patients included information regarding cyst rupture during surgery. Overall 28 (62\%) cysts ruptured during removal and 17 (38\%) cysts were removed intact. Of the 59 patients whose records specified that irrigation with a scolicidal agent was performed during surgery, the agent used was hypertonic saline in 48 patients, hypertonic saline + povidone-iodine in five, hydrogen peroxide

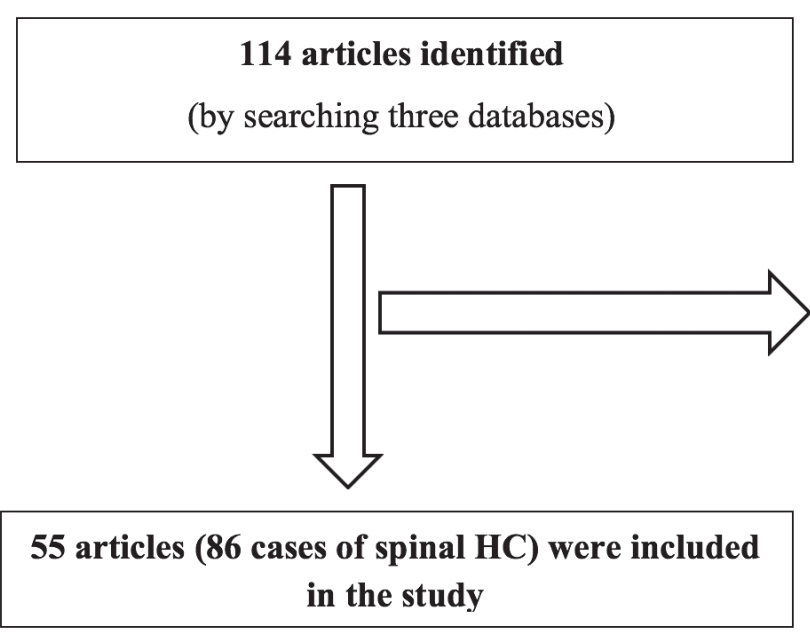

\section{9 articles were not included in the analysis}

- $\quad$ Not related to $\mathrm{HC} \mathrm{(3)}$

- Not related to spinal HC (14)

- Intracranial HC (11)

- Review/book chapter (11)

- Letter to the editor (3)

- Insufficient clinical data, radiological presentation (12)

- Full text not available (2)

- Caused by Echinococcus multilocularis (2)

- Previously published as case report (1)

Figure 1. Study flowchart and selection of suitable publications*

${ }^{*}$ Created according to reference 8. HC: Hydatid cyst 
in three, and one patient each with chlorhexidine, ethanol, and formaldehyde. Seventy-six of the patients underwent surgery followed by anthelmintic therapy, six patients underwent surgical treatment only, and two patients received anthelmintic treatment only. The anthelmintic agent used was albendazole in 61 patients and mebendazole in 17 patients. In patients for whom dosage was indicated, albendazole was administered at $800 \mathrm{mg} /$ day to 20 patients, $10-15 \mathrm{mg} / \mathrm{kg} /$ day to 16 patients, and $400 \mathrm{mg} /$ day to three patients. Mebendazole was administered at $60 \mathrm{mg} / \mathrm{kg} /$ day to 13 patients, and at $40-50 \mathrm{mg} / \mathrm{kg} /$ day to the others. Duration of medical treatment was reported in 52 patients and the mean was $6.9 \pm 10.4$ months (1-72 months). Albendazole or mebendazole was administered to 21 patients for six months, 11 patients for three months, and five patients for 12 months.

Of the 76 patients with data regarding prognosis after treatment, near complete resolution of symptoms after surgery was noted in 46 patients (61\%) patients. Thirteen patients (17\%) survived with severe neurological deficits (e.g., paraplegia, neurogenic bladder, severe muscle weakness), nine (12\%) with moderate deficit, and four (5\%) with mild deficit, while four patients (5\%) died (Table 4). Of these nonsurvivors, two died due to renal complications after nephrectomy for renal HC and one due to respiratory arrest secondary to toxic myelitis associated with intraoperative formaldehyde irrigation. The other deceased patient underwent two additional surgeries due to SHC recurrence, developed paraplegia, and died during the course of follow-up. The mean follow-up time after treatment was $49.1 \pm 54.8$ months (1-240 months). Analysis of the patients' histories (32 patients) in combination with follow-up period (12 patients) revealed that 44 patients (51\%) had at least one recurrence after treatment, and 32 patients (37\%) underwent multiple spinal surgeries.

\section{Discussion}

Although HC may involve any bone of the body, spinal involvement is most common $(45-54 \%)^{[3,4]}$. In a larger series including SHC patients from different countries, no significant difference in sex distribution was observed and the mean age was 35 years $^{[6]}$. Parasite growth within the bone is relatively slower compared to the liver and lung. Hence, the disease can remain asymptomatic for many years. Therefore, SHC is rarely observed in childhood and is more common in middleaged adults ${ }^{[6,7]}$. Similar to the literature, we found that $56 \%$ of the patients in our study were male and the mean age was $36.4 \pm 16.8$ years.

The clinical presentation of SHC is determined by signs and symptoms associated with spinal cord compression and vertebral
Table 1. Patients' history of spinal hydatid cyst (HC) and extraspinal $\mathrm{HC}$ and presence of concurrent extraspinal $\mathrm{HC}$ during the spinal $\mathrm{HC}$ diagnosis

\begin{tabular}{l|l}
\hline & Patient number (\%) \\
\hline History of surgery for spinal HC $(n=86)$ & $31(36)$ \\
\hline $\begin{array}{l}\text { History of surgery for extraspinal HC } \\
(n=86)\end{array}$ & $10(11.6)$ \\
\hline Concurrent extraspinal HC screened $(n=74)$ & $26(35.1)$ \\
\hline HC: Hydatid cyst
\end{tabular}

Table 2. Patients' microbiological test results

\begin{tabular}{l|l}
\hline & Patients with positive result (\%) \\
\hline IHA $(n=27)$ & $17(63)$ \\
\hline ELISA $(n=12)$ & $6(50)$ \\
\hline WB $(n=6)$ & $2(33.3)$ \\
\hline IFA $(n=1)$ & $1(100)$ \\
\hline $\begin{array}{l}\text { *Some patients underwent multiple tests. } \\
\text { IHA: Indirect hemagglutination assay, WB: Western blotting, IFA: Immunofluorescence } \\
\text { antibody assay, ELISA: Enzyme-linked immunosorbent assay }\end{array}$
\end{tabular}

Table 3. Patient categories according to Dew/Braithwaite \& Lees classification

\begin{tabular}{|c|c|}
\hline \multicolumn{2}{|l|}{ Unspecified category $(n=21)$} \\
\hline \multicolumn{2}{|l|}{ Category specified $(n=65)$} \\
\hline Category & Patient number (\%) \\
\hline Extradural-intraspinal & $16(24.6)$ \\
\hline $\begin{array}{l}\text { Extradural-intraspinal + paravertebral } \\
\text { (dumbbell formation) }\end{array}$ & $6(9.2)$ \\
\hline $\begin{array}{l}\text { Extradural-intraspinal + vertebral + } \\
\text { paravertebral }\end{array}$ & $4(6.1)$ \\
\hline Vertebral & $12(18.4)$ \\
\hline Vertebral + paravertebral & $10(15.3)$ \\
\hline Intradural-extramedullary & $13(20)$ \\
\hline Paravertebral & $2(3)$ \\
\hline Intramedullary & $2(3)$ \\
\hline
\end{tabular}

Table 4. The patients' postoperative prognosis

\begin{tabular}{l|l}
\hline Postoperative prognosis $(\mathbf{n = 7 6 )}$ & $\begin{array}{l}\text { Patient number } \\
(\mathbf{\%})\end{array}$ \\
\hline Full recovery & $46(61)$ \\
\hline Recovery with mild deficit & $4(5)$ \\
\hline Recovery with moderate deficit & $9(12)$ \\
\hline Recovery with severe deficit & $13(17)$ \\
\hline Death & $4(5)$
\end{tabular}

destruction. Depending on the level of spinal involvement and the degree of cord compression, patients can have dermatomal peripheral sensory loss, radicular pain, paraparesis, paraplegia, and/or anal sphincter or bladder dysfunction. Since the disease is slow-progressing, the time from symptom onset to diagnosis 
can be long ${ }^{[3,5,7,64]}$. In our study, the mean time elapsed between symptom onset and diagnosis was $9.93 \pm 21.06$ months.

In daily practice, SHC is diagnosed primarily via imaging methods, and serological tests are used more to confirm the diagnosis. Regardless of cyst location, the sensitivity of serological tests is closely associated with whether the cyst intact; since patients with cyst leakage or rupture show a strong serological response ${ }^{[65]}$. The widely used ELISA and IHA tests have similar specificity and sensitivity, and both are recommended as screening tests ${ }^{[6,67]}$. In our study, only $57 \%$ of the patients who underwent microbiological tests specific for E. granulosus had at least one positive result. Because the sensitivity of serological tests is dependent on cyst integrity, it has been emphasized that negative serological test results do not rule out a diagnosis of $\mathrm{HC}$ in patients with signs suggestive of $\mathrm{HC}$ in radiological imaging ${ }^{[68]}$. Magnetic resonance imaging and $\mathrm{CT}$ are currently the commonly used imaging methods in SHC diagnosis. Myelography is no longer recommended since it has low diagnostic value and can cause cyst rupture. While CT detect damaged bone tissue better, MRI may be preferable in terms of showing HC-specific signs, such as botryroid appearance, lack of gadolinium staining on the cyst wall, and demonstrating involvement of both bone and adjacent tissues ${ }^{[3,64,65,69]}$. In our study, MRI was the most frequently used imaging method (86\%).

Primary SHC was reported to be more common than secondary SHC, with the rate of secondary involvement being $18 \%$ in a large series. However, this rate may be affected by the fact that the extraspinal screening to distinguish between primary and secondary disease was not performed in all patients. In the same study, the authors observed a statistically significant association between lung $\mathrm{HC}$ and thoracic vertebral $\mathrm{HC}^{[5]}$. In our study, there was no significant association between thoracic vertebral involvement and lung $\mathrm{HC}(\mathrm{p}=0.544)$. Of the 74 patients who were screened for $\mathrm{HC}$ screening outside the spinal region, concurrent extraspinal $\mathrm{HC}$ was detected in $26(35 \%)$. Of the 78 patients in whom primary/secondary disease could be distinguished based on extraspinal screening and history of $\mathrm{HC}, 44$ (56.4\%) had primary SHC and 34 (43.5\%) had secondary involvement.

SHC often involves the thoracic (45-50\%) and lumbar (20$39 \%)$ vertebra. The higher frequency of thoracic and lumbar involvement is attributed to the dense vascularization in these regions. According to the Dew/Braithwaite \&t Lees classification, extradural intraspinal is the most common type, followed by vertebral and paravertebral SHC. Intramedullary SHC is rare $\mathrm{e}^{[5,7]}$. In this study, thoracic involvement was the most common (36\%), followed by lumbar (21\%), sacral (9\%), and cervical (6\%) involvement. The most common type was extradural intraspinal followed by vertebral and intradural extramedullary. Only two patients had intramedullary SHC. According to the literature, the intradural extramedullary type $\mathrm{SHC}$ is associated with more acute development of neurological symptoms and at a younger age. This is attributed to early spinal cord compression due to the tendency for the cyst to grow in the direction of least resistance ${ }^{[5]}$. In our study, there was no significant difference in age between the lesion categories $(p=0.61)$.

The main principle of SHC treatment is surgical removal of the unruptured cyst, decompression surgery to eliminate cord compression, and spinal stabilization ${ }^{[4,7,64]}$. However, due to the nature of $\mathrm{SHC}$, it is usually not possible to remove the cyst intact and unruptured. In a study on bone $\mathrm{HC}$, it was reported that complete excision of the lesion was achieved in only $16 \%$ of the cases $^{[4]}$. In the event of cyst rupture, washing the surgical area with scolicidal solution is recommended. Although hydrogen peroxide, povidone-iodine, $0.5 \%$ silver nitrate, and 10\% formaldehyde solutions have all been used for this purpose, $20 \%$ hypertonic saline is the commonly used and recommended scolicidal solution ${ }^{[3,7,70]}$. In the present study, cysts were removed intact in only $38 \%$ of the patients, and $20 \%$ hypertonic saline was the most commonly used scolicidal solution.

Since it is considered to have better oral bioavailability and cyst penetration, the current recommendation for first choice in the medical treatment of $\mathrm{HC}$ is albendazole at a dose of $10-15 \mathrm{mg} /$ $\mathrm{kg} / \mathrm{day}$. The combination of albendazole and praziquantel is also recommended. If albendazole is not available, mebendazole may be used ${ }^{[4,7,70]}$. Continuous use of albendazole is now recommended instead of the conventional intermittent treatment protocol involving cycles of four weeks of treatment and two weeks off therapy ${ }^{[70]}$. Albendazole and mebendazole are used as complementary medical treatment after surgery to prevent recurrence of SHC. However, the actual contribution of medical treatment to recurrence prevention is debated. There are still uncertainties regarding treatment scheme and duration. There is no staging system or treatment protocol for $\mathrm{SCH}$ like those established for liver and lung $\mathrm{HC}^{[70]}$. Since the pharmacokinetic characteristics of benzimidazoles in bone and spinal soft tissue are unknown, visceral organ $\mathrm{HC}$ treatment scheme is applied usually ${ }^{[4,7]}$. In the present study, we determined that albendazole at a dose of $10-15 \mathrm{mg} / \mathrm{kg} /$ day for six months was the most commonly preferred regimen. Medical treatment was initiated preoperatively in one patient and postoperatively in the other patients. A study analyzing treatment approaches in bone HC demonstrated no significant difference in recurrence rates with anthelmintic therapy for less than three months versus more than 6 months, or with initiating medical treatment preoperatively ${ }^{[4]}$. Although the role of albendazole in preventing recurrence is controversial, it is the only treatment option for inoperable $\operatorname{cases}^{[3,4,7]}$. In addition, it has been stated that although medical treatment may not prevent recurrence, it can delay $i^{[6]]}$. We could not evaluate the relationship between treatment protocols and recurrence due to variability in both follow-up time and medical treatment duration in the patients in our 
study, SHC is associated with high recurrence rates and several repeated surgical interventions. Approximately 40\% of patients are reported to develop symptomatic recurrence developed within two years after the initial operation ${ }^{[68]}$. Unruptured cyst removal and level of the lesion are factors affecting the prognosis, and repeated surgeries further increase the risk of paraplegia ${ }^{[7,65,71]}$. In a study on bone $\mathrm{HC}$, concurrent bone and visceral organ involvement and spinal involvement were identified as variables that were significantly correlated with recurrence ${ }^{[4]}$. In our study, evaluation of the history of patients as well as follow-up period together showed that 44 patients (51\%) had at least one recurrence after treatment and 32 patients (37\%) underwent multiple spinal surgeries. Due to the risk of recurrence, long-term follow-up of SHC cases is recommended even in the absence of symptoms. Since serological tests may remain elevated even after successful removal of the cyst, recurrence is defined by the patients' clinical and radiological imaging findings ${ }^{[70]}$. Similarly, presented patients' recurrence was diagnosed based on their clinical and radiological imaging findings.

Limitations of our study are that the data were collected retrospectively and not all target variables were specified in all of the articles when analyzing studies via the pooled analysis method. The studies were varying both in terms of dose and duration of anthelmintic drugs, as well as duration of follow-up, which precluded evaluations regarding the effect of treatment protocols on recurrence or prognosis.

\section{Conclusion}

SHC is still a difficult to treat disease. It has a high likelihood of recurrence, and affects the young/middle-aged population, potentially leading to death or morbidities that reduce quality of life and cause workforce loss, such as difficulty in walking, paraplegia, and urinary or fecal incontinence. There is a clear need for further research to determine effective treatment protocols for anthelmintic drugs, as well as programs for the prevention and control of hydatid disease in endemic regions such as Turkey.

\section{Ethics}

Ethics Committee Approval: Due to the fact that data of study was a systmatic review, Ethics Committee Approval was not taken.

Informed Consent: It was not received.

Peer-review: Externally and internally peer-reviewed.

\section{Authorship Contributions}

Concept: B.M.S., Design: B.M.S., Data Collection or Processing: B.M.S., G.Ç., Analysis or Interpretation: B.M.S., G.Ç., Literature Search: B.M.S., Writing: B.M.S.
Conflict of Interest: No conflict of interest was declared by the authors.

Financial Disclosure: The authors declared that this study received no financial support.

\section{References}

1. Dakkak A. Echinococcosis/hydatidosis: a severe threat in Mediterranean countries. Vet Parasitol. 2010;174:2-11.

2. Moro P, Schantz PM. Echinococcosis: a review. Int J Infect Dis. 2009;13:125-33.

3. Monge-Maillo B, Chamorro Tojeiro S, López-Vélez R. Management of osseous cystic echinococcosis. Expert Rev Anti Infect Ther. 2017;15:1075-82.

4. Steinmetz S, Racloz G, Stern R, Dominguez D, Al-Mayahi M, Schibler M, Lew $D$, Hoffmeyer $P$, Uçkay I. Treatment challenges associated with bone echinococcosis. J Antimicrob Chemother. 2014;69:821-6.

5. Neumayr A, Tamarozzi F, Goblirsch S, Blum J, Brunetti E. Spinal cystic echinococcosis-a systematic analysis and review of the literature: part 1. Epidemiology and anatomy. PLoS Negl Trop Dis. 2013;7:2450.

6. Braithwaite PA, Less RF. Vertebral hydatid disease: Radiological assessment. Radiology. 1981;140:763-6.

7. Neumayr A, Tamarozzi F, Goblirsch S, Blum J, Brunetti E. Spinal cystic echinococcosis-a systematic analysis and review of the literature: part 2. Treatment, follow-up and outcome. PLoS Negl Trop Dis. 2013;7:2458.

8. Preferred Reporting Items for Systematic Reviews and Meta-Analyses (PRISMA) Last accessed date: 15 November 2018, Available from: http:// www.prisma-statement.org

9. Gezercan Y, Ökten Al, Çavuş G, Açık V, Bilgin E. Spinal Hydatid Cyst Disease. World Neurosurg. 2017;108:407-17.

10. Senol N, Kerman M, Ozturk A, Ucmakli E. A Rare Parasitic Infection: Primary Intradural Extramedullary Hydatid Cyst. Turk Neurosurg. 2016;26:460-2.

11. Karakasli A, Yilmaz $M$, Mucuoglu A0, Yurt A. A large primary dumbbell hydatid cyst causing neural foraminal widening of the thoracic spine: $A$ case report and literature review. Int J Surg Case Rep. 2015;8:55-8.

12. Dogan I, Kahilogullari G, Guner E, Unlu A. A rare and unexpected clinical progress and location on a primary extradural spinal hydatid cyst in a pediatric patient: a case report. Childs Nerv Syst. 2015;31:1407-11.

13. Türk O, Özdemir NG, Atcı B, Katar S, Yılmaz H, Antar V, Karakaş E. Recurrent Primary Spinal Cyst Hydatid. Cukurova Medical Journal. 2015;40:84-9.

14. Kural C, Solmaz I, Ekberov A, Hodaj I, Pusat S, İzci Y. Primary spinal hydatid cyst involving the vertebra and paravertebral muscles: a case report. Gulhane Medical Journal. 2012;54:82-5.

15. Güzel $Y$, Kaçıra BK, Göncü $R$, Güleç $A$, Kütahya $H$, Yel M. Hydatid cyst of sacrum affecting the sakroiliac joint: a case report. The Journal of Turkish Spinal Surgery. 2013;24:157-60.

16. Özdemir K, Korucu M, İbrahimoğlu, M, Kaya C, Özdemir M, Çırak B. A rare and dangerous infectious lesion: Hydatid disease of the cervical spine. J Clin Exp Invest. 2014;5:452-5.

17. Somay H, Ayan E, Turk CC, Emon ST, Berkman MZ. Long-term disseminated recurrence in spinal hydatid cyst: a case report. Turk Neurosurg. 2014;24:78-81.

18. Günaldı Ö, Ofluoğlu EA, Kına H, Postalcı LŞ, Akdemir H. Spinal hydatid disease: three cases presentation. The Journal of Turkish Spinal Surgery. 2013;24:309-16

19. Caglar S, Bozkurt M, Kahilogullari G, Özdemir M. Management of a Rare and Dangerous Infectious Lesion: Hydatid Cyst Disease of the Odontoid Process. World Spinal Column Journal. 2012;3:29-32.

20. Akesen B, Ermutlu C, Aydınlı U. Spinal hydatidosis: report of a case treated by three level corpectomy, anterior and posterior instrumentation. The Journal of Turkish Spinal Surgery. 2011;22:45-50. 
21. Ediz L, Tekeoglu I, Ceylan MF, Avcu S, Hiz Ö. Paraplegia due to Spinal Extradural Hydatid Disease and Syringomyelia after Surgical Intervention: A Case Report. Turk J Phys Med Rehab. 2011;57:182-5.

22. Özmen A, Bekar A, Tolunay Ş, Heper Y, Yılmaz E, Helvacı S, Aktaş U. A Case of Spinal Intradural Extramedullary Hydatid Cyst Mimicking a Spinal Tumor. Turkiye Klinikleri Journal of Medical Sciences. 2013;33:572-5.

23. Erdem MN, Sever C, Korkmaz MF, Oltulu i, Gürgen E, Tezer M. Vertebral hydatid disease and its treatment by anterior-posterior radical excision, fusion and chemotherapy with albendazole case report-eleven years follow-up result. The Journal of Turkish Spinal Surgery. 2013;24:317-20.

24. Atan T, Taşkıran ÖÖ, Göğüş F. Progressive Primary Spinal Hydatid Cyst: A Case Report. Turk J Phys Med Rehab. 2013; 59:345-8.

25. Gezgin S, Sanal HT. "Water-lily sign" as a rare finding of spinal hydatidosis. Spine J. 2012;12:5-7.

26. Senol MG, Tekeli H, Kendirli MT, Kaya S, Turhan V, Sonmez G, Saracoglu M. Intramedullary hydatid cyst of the cervical spine. Indian J Med Microbiol. 2012;30:480-1.

27. Yildiz S, Komur E, Akti Z, Karabag H. Infected primary paraspinal hydatidosis with water lily sign. J Emerg Med. 2012;43:989-91.

28. Döngel I, Bayrakli F, Nadir A. An Unusual Cause of Paraplegia: Extradural Intraspinal Hydatid Cyst. Journal of Neurological Sciences (Turkish). 2012;29:847-50.

29. Ozdemir O, Calisaneller T, Yildirim E, Altinors N. Percutaneous CT-guided treatment of recurrent spinal cyst hydatid. Turk Neurosurg. 2011;21:685-7.

30. Diktaş H, Cakmak S, Turhan V, Kantemir A, Güleç B, Öncül O, Rodop O, Öztürk $E$, Görenek L. Hydatid cyst presenting with multiple recurrence and pelvic involvement: case report. Turkiye Parazitol Derg. 2011;35:178-80.

31. Erayman I, Kalkan E, Erdi F, Kerimoglu Ü, Esen H. Primary spinal hydatid cyst in a patient with acquired immunodeficiency syndrome. Eur Spine J. 2011;20:235-8.

32. Kotil $K$, Tari $R$, Savas $Y$. Medical treatment of primary extradural solitary lumbar hydatid disease. J Clin Neurosci. 2010;17:793-5.

33. Celik C, Sasmaz MF, Oktay F, Ucan H, Kaptanoglu E. Paraplegia associated with spinal hydatid cyst: a case report. Spine. 2010;35:356-8.

34. Güneç $M$, Akdemir $H$, Tuğcu $B$, Günaldi $O$, Gümüç $E$, Akpinar A. Multiple intradural spinal hydatid disease: a case report and review of literature. Spine. 2009;34:346-50.

35. Bilgic S, Kose O, Sehirlioglu A, Safaz I, Ozkan H. Primary paraspinal hydatid cyst treated with puncture, aspiration, injection and re-aspiration (PAIR) technique: a case report. Eur Spine J. 2009;18:165-7.

36. Turan Süslü $H$, Ceçen $A$, Karaaslan A, Börekçi $A$, Bozbuğa M. Primary spinal hydatid disease. Turk Neurosurg. 2009;19:186-8.

37. Senoglu M, Bulbuloglu E, Demirpolat G, Altun I, Celik M. Combined anterior and posterior approach for sacral/retroperitoneal hydatid cyst disease: case report. Turk Neurosurg. 2009;19:428-32.

38. Midyat L, Gökçe $S$, Onder A, Ozdemir Y, Mursalov G, Mir S. A very rare cause of childhood paraparesis: primary intradural extramedullary spinal hydatid cyst. Pediatr Infect Dis J. 2009;28:754-5.

39. Salduz A, Koyuncu LO, Dikici F, Talu U. Long-term result of treatment for paraspinal and extradural hydatid cyst: a case report. Acta Orthop Traumatol Turc. 2009;43:267-71.

40. Secer HI, Anik I, Celik E, Daneyemez MK, Gonul E. Spinal hydatid cyst mimicking arachnoid cyst on magnetic resonance imaging. J Spinal Cord Med. 2008;31:106-8.

41. Doganay $S$, Kantarci M. Role of conventional and diffusion-weighted magnetic resonance imaging of spinal treatment protocol for hydatid disease. J Spinal Cord Med. 2009;32:574-7.
42. Kalkan E, Torun F, Erdi F, Baysefer A. Primary lumbar vertebral hydatid cyst. J Clin Neurosci. 2008;15:472-3.

43. Tuğcu B, Günaldi 0 , Güneş $M$, Güler AK, Adilay U, Eseoğlu M, Günal M, Aliş H. Hydatid cysts in uncommon locations in the same patient: simultaneous cardiac and spinal involvement. Minim Invasive Neurosurg. 2008;51:234-6.

44. Sengul G, Kadioglu HH, Kayaoglu CR, Aktas S, Akar A, Aydin IH. Treatment of spinal hydatid disease: a single center experience. J Clin Neurosci. 2008; 15:507-10.

45. Kalkan E, Cengiz SL, Ciçek O, Erdi F, Baysefer A. Primary spinal intradural extramedullary hydatid cyst in a child. J Spinal Cord Med. 2007;30:297-300.

46. Kotil K, Tatar Z, Bilge T. Spinal hydatidosis accompanied by a secondary infection. Case report. J Neurosurg Spine. 2007;6:585-90.

47. Tabak O, Yilmaz M, Oz B, Ozaras R, Erdincler P, Mert A, Ozturk R, Tabak F. A vertebral hydatid cyst infection mimicking tuberculous spondylodiscitis. Infect Chemother. 2007;13:180-2.

48. Çalık M, Çalık, SG, Esme H. Vertebral Hydatid Disease: White Cancer. Respir Case Rep. 2017;6:103-6.

49. Kahilogullari G, Tuna $H$, Aydin $Z$, Colpan E, Egemen N. Primary intradural extramedullary hydatid cyst. Am J Med Sci. 2005;329:202-4.

50. Selçuk B, Çolak Y, Uraloğlu, G, Kurtaran A, Ersöz M, Palaoğlu S, Akyüz M. An Unusual Cause of Paraplegia: Spinal Hydatid Cyst (Case Report). Turk J Phys Med Rehab. 2005;51:114-6.

51. Taşdemir N, Taşdemir, MS, Toksöz M, Hoşoğlu S. Santral sinir sistemi kist hidatiği: iki olgu. Tıp Araştırmaları Derg. 2005;3:41-4.

52. Bayram BK, Avcı S, Koçyiğit H, Gelal F, Gürgan A. Hydatid Cyst of the Spine: A Case Report. Turk J Phys Med Rehab. 2005;51:146-9.

53. Bozbuga M, Celikoglu E, Boran BO. Hydatid cyst of the craniocervical junction: case report. Neurosurgery. 2005;57:193.

54. Özdemir HM, Ögün TC, Tasbas B. A lasting solution is hard to achieve in primary hydatid disease of the spine: long-term results and an overview. Spine (Phila Pa 1976). 2004;29:932-7.

55. Sarıgül A, Özpolat B, Gökaslan G, Kaya M, Yücel E. Primer torakal vertebral epidural kist hidatik. Medical Network Klinik Bilimler ve Doktor. 2004;10:653-5.

56. Kaptanoglu $E_{1}$ Dural K, Beskonaklı E, Kara C, Ergungor F. Recurrence of Primary Costal Echinococcosis with Spinal Cord Compression. Turk Neurosurg. 2002;12:116-9.

57. Karadereler S, Orakdögen M, Kiliç K, Ozdogan C. Primary spinal extradural hydatid cyst in a child: case report and review of the literature. Eur Spine J. 2002;11:500-3.

58. Bilgen C, Oner K, Ovül I, Kirazli T. Vertebral hydatid disease presenting as a parapharyngeal and neck mass: a case report. Otolaryngol Head Neck Surg. 2002;126:89-90.

59. Yildiz Y, Bayrakci K, Altay M, Saglik Y. The use of polymethylmethacrylate in the management of hydatid disease of bone. J Bone Joint Surg Br. 2001;83:1005-8.

60. Baykaner MK, Doğulu F, Oztürk G, Edali N, Tali T. A viable residual spinal hydatid cyst cured with albendazole. Case report. J Neurosurg. 2000;93:1424.

61. Işlekel S, Erşahin Y, Zileli M, Oktar N, Oner K, Ovül I, Ozdamar N, Tunçbay E. Spinal hydatid disease. Spinal Cord. 1998;36:166-70.

62. Keskin F, Erdi F, Kalkan E, Karatas Y. Recurrence of Primary Spinal Cyst Hydatid in a HIV (+) Patient: A Case Report. J Neurol Sci (Turkish). 2013;30:455-60.

63. Onbas 0 , Kantarci M, Alper F, Sekmenli N, Okur A. Spinal widespread intradural extramedullary hydatidosis. Neuroradiology. 2004;46:310-2.

64. Kıter E, Benli iT, Karagüven D. Omurganın kist hidatik hastalığı. İçinde: Benli iT (ed). Omurga enfeksiyonları. Ankara: Türk Omurga Derneği Yayınları-4, 2016:579-92. 
65. Herrera A, Martínez AA, Rodriguez J. Spinal hydatidosis. Spine (Phila Pa 1976). 2005;30:2439-44.

66. Yılmaz GR, Babür C. Diagnosis of Echinococcosis. Turk Hij Den Biyol Derg. 2007;64:35-44.

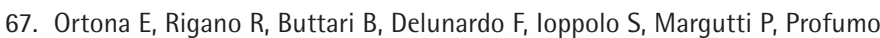
$E$, Teggi A, Vaccari S, Siracusano A. An update on immunodiagnosis of cystic echinococcosis. Acta Trop. 2003;85:165-71.

68. Pamir N, Özdamar K, Elmac I. Spinal hydatid disease. Spinal Cord. 2002;40:153-60.
69. El Quessar A, Jroundi L, Tizniti S, Cissé M, Chakir N, El Hassani MR, Benchaâboun $\mathrm{H}$, Jiddane $\mathrm{M}$. CT and MRI features of spinal hydatidosis. A report of 8 cases. J Radiol. 2001;82:917-21.

70. Brunetti E, Kern P, Vuitton DA; Writing Panel for the WHO-IWGE. Expert consensus for the diagnosis and treatment of cystic and alveolar echinococcosis in humans. Acta Trop. 2010;114:1-16.

71. Kafaji A, Al-Zain T, Lemcke J, Al-Zain F. Spinal manifestation of hydatid disease: a case series of 36 patients. World Neurosurg. 2013;80:620-10. 